\title{
Administration of Atrial Natriuretic Factor Inhibits Sodium-coupled Transport in Proximal Tubules
}

\author{
Timothy G. Hammond, Ahad N. K. Yusufi, Franklyn G. Knox, and Thomas P. Dousa \\ Nephrology Research Unit and Department of Physiology and Biophysics, Mayo Medical School, Rochester, Minnesota 55905
}

\begin{abstract}
The newly discovered peptides extracted from cardiac atria, atrial natriuretic factors (ANFs), when administered parenterally cause renal hemodynamic changes and natriuresis. The nephron sites and cellular mechanism accounting for profound increase in $\mathrm{Na}^{+}$excretion in response to ANFs are not yet clarified. In the present study we investigated whether synthetic ANF peptide alters the reabsorption of $\mathrm{Na}^{+}$and reabsorption of solutes cotransported with $\mathrm{Na}^{+}$in the proximal tubules of rats. Synthetic ANF peptide consisting of 26 amino acids, $4 \mu \mathrm{g} / \mathrm{kg}$ body $w t / h$, or vehicle in controls, was infused to surgically thyroparathyroidectomized anesthetized rats. After determination of the fractional excretion (FE) of electrolytes $\left(\mathrm{Na}^{+}\right.$, $\mathrm{K}^{+}, \mathrm{P}_{\mathrm{i}}, \mathrm{Ca}^{2+}, \mathrm{Mg}^{2+}, \mathrm{HCO}_{3}$ ), the kidneys were removed and luminal brush border membrane vesicles (BBMVs) were prepared from renal cortex. Solute transport was measured in BBMVs by rapid filtration techniques. Infusion of ANF peptide increased $\mathrm{FE}_{\mathrm{Na}}, \mathrm{FE}_{\mathrm{P}_{1}}$, and $\mathrm{FE}_{\mathrm{HCO}_{3}}$; but $\mathrm{FE}_{\mathrm{Ca}_{a}}, \mathrm{FE}_{\mathrm{K}}$, and $\mathrm{FE}_{\mathrm{Mg}}$ were not changed. The increase in $\mathrm{FE}_{\mathrm{Na}}$ was significantly correlated, on the one hand, with increase of $\mathrm{FE}_{\mathrm{P}_{1}}(r=0.9, n$ $=7 ; P<0.01)$ and with increase of $\mathrm{FE}_{\mathrm{HCO}_{3}}(r=0.89, n=7$; $P<0.01)$. On the other hand, $F_{\mathrm{N}_{\mathrm{a}}}$ did not correlate with $\mathrm{FE}_{\mathrm{K}}, \mathrm{FE}_{\mathrm{Ca}}$, or with $\mathrm{FE}_{\mathrm{Mg}}$. The $\mathrm{Na}^{+}$gradient-dependent uptake of $P_{i}$ by BBMVs prepared from renal cortex of rats receiving ANF infusion was significantly $(P<0.05)$ decreased $(-25 \%)$, whereas the $\mathrm{Na}^{+}$gradient-dependent uptake of $L-\left[{ }^{3} \mathrm{H}\right]$ proline and of $\left.\mathrm{D}-\left.\right|^{3} \mathrm{H}\right]$ glucose or the diffusional uptake of ${ }^{22} \mathrm{Na}^{+}$were not changed. ANF-elicited change in $F_{P_{1}}$ showed a close inverse correlation with decrease of $\mathrm{Na}^{+}$-dependent $P_{i}$ uptake by BBMVs isolated from infused rats $(r=0.99, n=7 ; P$ $<0.001)$. Direct addition of ANF to BBMVs in vitro did not change the $\mathrm{Na}^{+}$gradient-dependent $P_{i}$ uptake. In rats infused with $A N F$, the rate of amiloride-sensitive $\mathrm{Na}^{+}-\mathrm{H}^{+}$exchange across the brush border membrane (BBM) was significantly $(P<0.05)$ decreased $(-40 \%)$, whereas the diffusional ${ }^{22} \mathrm{Na}^{+}$ uptake $(0.5 \mathrm{~min})$ and the equilibrium $(120 \mathrm{~min})$ uptake of ${ }^{22} \mathrm{Na}^{+}$were not changed. The inhibition of $\mathrm{Na}^{+}-\mathrm{H}^{+}$exchange after ANF was likely due to alteration of the BBM antiporter itself, in that the $\mathrm{H}^{+}$conductance of BBMVs was not increased. We conclude that synthetic ANF (a) decreases tubular $\mathrm{Na}^{+}$ reabsorption linked to reabsorption of $\mathrm{HCO}_{3}$ in proximal tubules, and $(b)$ inhibits proximal tubular reabsorption of $P_{i}$ coupled to $\mathrm{Na}^{+}$reabsorption, independent of secretion and/or
\end{abstract}

Address correspondence and reprint requests to Dr. Hammond or Dr. Dousa.

Received for publication 12 September 1984 and in revised form 28 January 1985.

J. Clin. Invest.

(C) The American Society for Clinical Investigation, Inc. $0021-9738 / 85 / 06 / 1983 / 07 \quad \$ 1.00$

Volume 75, June 1985, 1983-1989 action of parathyroid hormone or calcitonin. These ANF effects are associated with inhibition of $\mathrm{Na}^{+}-\mathrm{P}_{\mathbf{i}}$ synport and of $\mathrm{Na}^{+}-$ $\mathrm{H}^{+}$antiport in luminal BBMs. Our findings document that inhibition of $\mathrm{Na}^{+}$-coupled transport processes in proximal tubules is an integral part of the renal response to ANF.

\section{Introduction}

Recently, a family of polypeptides extracted from cardiac atrial tissue, designated as cardiopeptins or atrial natriuretic factor (ANF), ${ }^{1}$ has been identified and subsequently chemically synthesized (1-4). The major known renal effects of these ANF peptides are natriuresis and changes in renal hemodynamics $(2,3)$. The natriuresis cannot be fully accounted for by changes in renal hemodynamics and/or physical factors governing in part tubular reabsorption of $\mathrm{Na}^{+}$(4), suggesting that ANF may inhibit directly the tubular transport of $\mathrm{Na}^{+}$. Unlike another recently described natriuretic factor (4), ANF has no effect on the activity of $\left(\mathrm{Na}^{+}-\mathrm{K}^{+}\right)$-ATPase (4-6) or $\mathrm{Na}^{+}$transport in amphibian epithelia $(5,6)$.

Another partially related problem, is the question whether ANF inhibits tubular $\mathrm{Na}^{+}$reabsorption in the proximal or in the distal segments of the mammalian nephron. Although the bulk of the filtered $\mathrm{Na}^{+}$is reabsorbed in proximal tubules, a few initial studies seem to locate ANF inhibition of $\mathrm{Na}^{+}$ reabsorption mainly in distal tubule segments $(7,8)$.

To address the question of whether or not ANF decreases tubular epithelial transport, namely in the proximal tubule, we studied the renal effects of infused synthetic rat $\mathrm{ANF}^{2}$ peptide $(9,10)$.

The design of our study is based on the following premises. The filtered phosphate $\left(\mathrm{P}_{\mathrm{i}}\right)$ is reabsorbed in proximal tubules via cotransport with $\mathrm{Na}^{+}(11,12)$, including secondary active $\mathrm{Na}^{+}$-dependent uptake of $\mathrm{P}_{\mathrm{i}}$ across the luminal brush border membrane (BBM) $(13,14)$.

$\mathrm{Na}^{+}$is reabsorbed across the epithelium of the proximal tubule through several pathways (15). One of these important pathways for $\mathrm{Na}^{+}$reabsorption in the proximal tubule is a $\mathrm{Na}^{+}$cotransport with the bicarbonate anion $\left(\mathrm{HCO}_{3}\right)(15,16)$. In this transport system, electroneutral $\mathrm{Na}^{+}-\mathrm{H}^{+}$antiport at the luminal BBM of proximal tubule (17) is the initial step in

1. Abbreviations used in this paper: $\mathrm{ANF}$, atrial natriuretic factor; $\mathrm{AO}$, acridine orange; BBM, brush border membrane; BBMV, brush border membrane vesicle; BP, blood pressure; FE, fractional excretion; GFR, glomerular filtration rate; P, plasma; PTH, parathyroid hormone; TPTX, thyroparathyroidectomy.

2. The atrial natriuretic factor used in this study is a synthetic polypeptide, which corresponds to the C-terminal polypeptide chain of 26 amino acid residues derived from the larger 73-amino acid precursor form of ANF (9), with sequence Arg-Arg-Ser-Ser-Cys-PheGly-Gly-Arg-Ile-Asp-Arg-Ile-Gly-Ala-Gln-Ser-Gly-Leu-Gly-Cys-AsnSer-Phe-Arg-Tyr-COOH. A disulfide bridge links cysteines at positions 5 and 21 (9). 
$\mathrm{Na}^{+}$-linked reabsorption of $\mathrm{HCO}_{3}$ and proximal tubular acidification $(15,16)$.

Therefore, if ANF inhibits $\mathrm{Na}^{+}$reabsorption in proximal tubules, we can expect that $\mathrm{Na}^{+}-\mathrm{P}_{\mathrm{i}}$ synport and $\mathrm{Na}^{+}-\mathrm{H}^{+}$ antiport across BBMs to be inhibited with a concomitant phosphaturia and bicarbonaturia.

With these considerations in mind, we studied the effects of the synthetic ANF (referred to as "ANF peptide" throughout the following text) on fractional excretion (FE) of $\mathrm{Na}^{+}, \mathrm{P}_{i}$, $\mathrm{HCO}_{3}$, and other electrolytes, as well as transport properties of the BBM vesicles (BBMVs) isolated from kidneys of the same animals.

\section{Methods}

Animals. Wistar rats of either sex weighing $200-225 \mathrm{~g}$ were fed standard rat diet containing $0.61 \%$ phosphorus (Ralston-Purina, Richmond, IN) ad libitum, with free access to water.

General experimental design. The studies were designed to minimize variability and to allow paired comparisons $(18-20)$. To this end, animals that received infusion of ANF peptide and control animals that received vehicle were taken into the experiment on the same day, using the same set of solutions, biochemicals, and the same timing. Moreover, at the end of the clearance procedure, the BBMVs were prepared from kidneys of rats infused with ANF and from the controls at the same time, and transport measurements were also conducted simultaneously using the same radiochemicals, biochemicals, and standards. Therefore, glomerular filtration rate (GFR) and FE of electrolytes and subsequent transport studies on isolated BBMVs were determined simultaneously in two groups of rats.

Clearance experiments. On the day of the experiment the rats were anesthetized with Inactin $(100 \mathrm{mg} / \mathrm{kg})$ and prepared for clearance experiments. The animals were placed on a heated table, and body temperature was monitored with a rectal probe. A catheter was inserted into the carotid artery, and a basal blood sample was drawn. Acute thyroparathyroidectomy (TPTX) was performed by surgical removal of the glands and heat cautery. Adequacy of TPTX was confirmed in each group of rats by a fall in plasma calcium (ANF group: mean \pm SEM, $2.50 \pm 0.04 \mathrm{mM}$ before and $2.35 \pm 0.06 \mathrm{mM}$ after TPTX, $n=7, P$ $<0.05$; control group: $2.40 \pm 0.05 \mathrm{mM}$ before and $2.34 \pm 0.04 \mathrm{mM}$ after TPTX, $n=8, P<0.05$ ). A tracheostomy was performed, and the animals were allowed to breathe spontaneously. A catheter was inserted into a jugular vein for infusion of $2 \%$ inulin in normal saline at 3.5 $\mathrm{ml} / \mathrm{h}$. Urinary losses were replaced through a second jugular catheter. A bladder catheter was inserted. After TPTX a 2-h recovery period was allowed for attainment of a steady state. In the first group ("ANF group"), a control clearance was performed before intravenous infusion at $4.0 \mu \mathrm{g} / \mathrm{kg}$ per h of ANF (Merck, Sharp \& Dohme, Rahway, NJ). After 20 min to obtain equilibrium of infused ANF, an experimental clearance was performed. In preliminary experiments, we found 4.0 $\mu \mathrm{g} / \mathrm{kg}$ per $\mathrm{h}$ to be a maximally natriuretic nonhypotensive dose of ANF in the rat.

The second group shared the identical protocol except vehicle only-without ANF-was infused. Immediately after completion of the clearance studies, the kidneys were removed and decapsulated, and the cortex was rapidly dissected out and placed immediately in icecold solution (154 mM NaCl, $1 \mathrm{mM}$ Tris-Hepes, $\mathrm{pH} 7.5$ ) for preparation of a BBMV fraction (21).

$B B M V$ transport studies. BBM fractions were prepared from homogenized renal cortical tissue by the slightly modified calcium precipitation procedure (2) described in full in our previous studies on rats $(18-20,22)$. The BBMVs were washed with $300 \mathrm{mM}$ mannitol, 5 $\mathrm{mM}$ Tris-Hepes ( $\mathrm{pH} \mathrm{8.5),} \mathrm{and} \mathrm{were} \mathrm{used} \mathrm{immediately} \mathrm{for} \mathrm{solute} \mathrm{uptake}$ studies, for measurement of $\mathrm{Na}^{+}-\mathrm{H}^{+}$exchange, or for testing of $\mathrm{H}^{+}$ efflux. All solutions used for the preparations of BBM fractions and for transport measurements were filtered through a $0.45-\mu \mathrm{m}$ filter (Millipore Corp., Bedford, MA) on the day of use.
Uptake of $\left.{ }^{32} \mathrm{P}\right]$ phosphate $(18-20,22)$ and $\mathrm{L}-\left[{ }^{3} \mathrm{H}\right]$ proline $(19,22)$ by isolated BBMVs was measured by the Millipore filtration technique $(18-20,22)$. Briefly, BBMVs $(\sim 0.1 \mathrm{mg}$ of protein) were suspended in a medium containing $100 \mathrm{mM}$ mannitol, $100 \mathrm{mM} \mathrm{NaCl}, 5 \mathrm{mM}$ TrisHepes (pH 8.5), and either $0.1 \mathrm{mM} \mathrm{K}_{2} \mathrm{H}^{32} \mathrm{PO}_{4}$ or $0.025 \mathrm{mM} \mathrm{L}$ $\left[{ }^{3} \mathrm{H}\right]$ proline (final concentrations). The uptake was measured at $20^{\circ} \mathrm{C}$ and was terminated at various times by addition of ice-cold $135 \mathrm{mM}$ $\mathrm{NaCl}, 10 \mathrm{mM}$ arsenate, 5 Tris-Hepes (pH 8.5). Uptake of ${ }^{22} \mathrm{Na}^{+}$was determined in the absence of $\mathrm{P}_{\mathrm{i}}$ or $\mathrm{L}-\left[^{3} \mathrm{H}\right]$ proline and by a similar procedure $(20,22)$ except that the incubation medium contained 100 $\mathrm{mM}$ mannitol, $100 \mathrm{mM} \mathrm{NaCl}, 5 \mathrm{mM}$ Tris-Hepes (pH 8.5), and ${ }^{22} \mathrm{NaCl}$ $\left(\sim 4 \times 10^{5} \mathrm{cpm} /\right.$ tube $)$, and the uptake was terminated by the rapid addition of an ice-cold solution of $150 \mathrm{mM} \mathrm{MgSO}_{4}$, buffered with 5

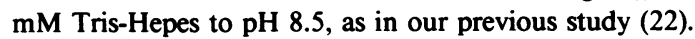

The rate of $\mathrm{Na}^{+}-\mathrm{H}^{+}$exchange was determined by using a rapid filtration technique $(23,24)$, basically as described by Frieberg et al. (19), except that we employed BBMVs prepared by the calcium precipitation method, and that the $\mathrm{pH}$ of the intravesicular medium was $\mathrm{pH} 6.0$ instead of 5.5. In the experiments when $\mathrm{Na}^{+}-\mathrm{H}^{+}$exchange across the BBM was measured, BBMVs were prepared as in other solute uptake studies (18-20), but were preloaded (13) by resuspending and washing of the BBMV fraction in an acidic medium (23) that contains $150 \mathrm{mM} \mathrm{KCl}, 25 \mathrm{mM}$ 2-( $N$-morpholino)-ethanesulfonic acid, $4.6 \mathrm{mM}$ Tris, adjusted with $\mathrm{KOH}$ to $\mathrm{pH}$ 6.0. The rate of $\mathrm{Na}^{+}-\mathrm{H}^{+}$ exchange was measured by incubation of BBMVs preloaded with acidic intravesicular medium in a medium containing $144 \mathrm{mM} \mathrm{KCl}$, $5 \mathrm{mM}$ 2-( $N$-morpholino)-ethanesulfonic acid, $13 \mathrm{mM}$ Tris, and 13 $\mathrm{mM}$ Hepes, adjusted with $\mathrm{KOH}$ to $\mathrm{pH} 7.5$, and containing $1 \mathrm{mM}$ ${ }^{22} \mathrm{Na}{ }^{+} \mathrm{Cl}\left(0.1 \mu \mathrm{Ci}\right.$ of ${ }^{22} \mathrm{Na}^{+}$per tube) in final volume of $45 \mu \mathrm{l}$. The incubation was terminated by addition of $3 \mathrm{ml}$ of ice-cold $\left(0-2^{\circ} \mathrm{C}\right)$ "stop solution" containing $150 \mathrm{mM} \mathrm{KCl}, 16 \mathrm{mM}$ Hepes, and $10 \mathrm{mM}$ Tris, adjusted with $\mathrm{KOH}$ to $\mathrm{pH} 7.5$ and rapid filtration (16), similarly as in other transport studies (12-15). Because the $\mathrm{Na}^{+}-\mathrm{H}^{+}$antiport in the renal BBM is specifically blocked by amiloride (17), the ${ }^{22} \mathrm{Na}^{+}$ uptake at $\mathrm{pH}$ gradient condition $\left(\mathrm{pH}_{\mathrm{i}}<\mathrm{pH}_{0}\right)$ was always measured simultaneously with and without addition of $1 \mathrm{mM}$ amiloride, the maximum inhibitory concentration of the compound (17). The amiloride-sensitive component of $\mathrm{Na}^{+}-\mathrm{H}^{+}$exchange $(\sim 50 \%)$ was less than that reported in studies on rabbit $(17,25)$ and comparable to results of canine (26) BBMVs prepared by the $\mathbf{M g}^{2+}$ precipitation procedure. This feature may be due to higher $\mathrm{H}^{+}$conductance of rat BBMVs prepared by the $\mathrm{Ca}^{2+}$ precipitation method (26).

The rate of $\mathrm{H}^{+}$efflux from BBMV was determined by using a method described by others $(18,20,25,26)$, which employs the quenching of acridine orange fluorescence as an indicator of the transmembrane proton gradient. Fluorescence was continuously monitored by using an AMINCO-Bowman spectrophotofluorometer (American Instrument Co., Silver Spring, MD) (excitation wavelength $493 \mathrm{~nm}$, emission $530 \mathrm{~nm}$ ) connected with a chart recorder. BBMVs were prepared at $\mathrm{pH} 6.0$ as described above for $\mathrm{Na}^{+}-\mathrm{H}^{+}$exchange measurements. The assay medium consisted of $6 \mu \mathrm{M}$ acridine orange (AO) $150 \mathrm{mM} \mathrm{KCl}, 10 \mathrm{mM}$ Tris-Hepes, pH 7.5. An aliquot $(20 \mu \mathrm{l})$ of BBMVs $(\sim 150 \mu \mathrm{g}$ of protein) equilibrated at $\mathrm{pH} 6.0$ to the medium (final volume $2 \mathrm{ml}$ ) resulted in rapid quenching (about $-40 \%$ ) of the AO fluorescence, which was followed by a slow increase in the fluorescence intensity as the imposed $\mathrm{pH}$ gradient dissipated. The addition of BBMVs equilibrated at $\mathrm{pH} 7.5\left(\mathrm{H}_{\mathrm{i}}^{+}=\mathrm{H}_{0}^{+}\right)$did not result in fluorescence quenching or in any time-dependent changes in fluorescence intensity. The rate of $\mathrm{H}^{+}$efflux was expressed in relative units (18). The quenching of AO fluorescence after addition of BBMVs was taken as $100 \%$. The rate of reappearance of the $A O$ fluorescence was expressed as the relative (percent) rate of increase, for 15- and 30-s intervals (see Table VI).

In BBM transport studies $(22-24,27,28)$, the final concentrations of radiolabeled solutes were $0.1 \mathrm{mM}\left[{ }^{32} \mathrm{P}_{\mathrm{i}}\right]$ phosphate, $0.025 \mathrm{mM} \mathrm{L}$ $\left[{ }^{3} \mathrm{H}\right]$ proline, $0.05 \mathrm{mM}\left[{ }^{3} \mathrm{H}\right]$ glucose, and $100 \mathrm{mM}^{22} \mathrm{Na}^{+} \mathrm{Cl}(21-23,29)$ In most experiments that examined the ${ }^{32} \mathrm{P}_{\mathrm{i}}$ uptake by BBMV, the uptake of $L-\left[{ }^{3} \mathrm{H}\right]$ proline was measured, for comparison, in the same aliquot of $\operatorname{BBMV}(22,29)$. 
The rates of uptake of ${ }^{22} \mathrm{Na}^{+}$and other solutes, as well as the $\mathrm{Na}^{+}-$ $\mathrm{H}^{+}$exchange are expressed in picomoles per milligram of BBMV protein per given time interval. In addition, the concentrative "uphill" $\mathrm{Na}^{+}$gradient-dependent uptake was also expressed in relative terms as a $\Delta \%$ ratio of solute uptake at the uphill phase to equilibrium phase (14, 21-23). In each BBM preparation, the uptake of solutes was measured in triplicate at each time period and the mean \pm SE was entered as $n=1$. Uptake by BBMVs from each of the control and ANF groups was always compared on the same day to avoid interassay variations. Protein was determined by the method of Lowry et al. (30) after solubilization of the samples in $1 \%$ sodium dodecyl sulfate, as in our previous studies $(21-23,29)$.

Other analytic methods. Activities of BBM enzymes, i.e., alkaline phosphatase and leucine aminopeptidase, were assayed using methods previously employed and described in studies from this laboratory (28, 29). The specific activities of these enzymes were measured under conditions in which enzyme reaction rates were linear with respect to incubation time and protein concentrations. There was no difference in specific activity of alkaline phosphatase or leucine aminopeptidase between BBMs prepared from ANF-treated rats and from untreated controls.

Phosphate content of plasma $\left(\mathrm{P}_{\mathrm{P}_{\mathrm{i}}}\right)$ and urine was measured by the method of Chen et al. (31), inulin by the anthrone method (32), $\mathrm{Na}^{+}$ and $\mathrm{K}^{+}$by flame photometry (23), and $\mathrm{Ca}$ and $\mathrm{Mg}$ by an atomic absorption spectrophotometer (Jarell-Ash Div., Fisher Scientific Co., Waltham, MA), as in previous studies $(21,22,28,29)$. Plasma bicarbonate was calculated from blood $\mathrm{pH}$ and $\mathrm{PCO}_{2}$ measured on a blood gas analyzer (Instrumentation Laboratory Inc., Lexington, MA), and urine bicarbonate was calculated from urinary $\mathrm{CO}_{2}$ content measured with a Natelson Microgasometer (Instrumentation Laboratory, Inc.), and urine pH (Instrumentation Laboratory, Inc.), as previously reported (33). Samples for urinary bicarbonate analysis were collected on mercury under oil. Plasma glucose was measured on a glucose oxidase analyzer (Beckman Instruments, Inc., Fullerton, CA).

Materials. Rats were supplied by Harlan Sprague Dawley, Inc. (Indianapolis, IN). ${ }^{32} \mathrm{P}_{\mathrm{i}}, \mathrm{L}-\left[{ }^{3} \mathrm{H}\right]$ proline, and ${ }^{22} \mathrm{Na}^{+}$were purchased from New England Nuclear (Boston, MA). Biochemicals, all of the highest purity grades available, were purchased from the Sigma Chemical Co. (St. Louis, MO) or other standard suppliers. Atrial natriuretic factor (ANF peptide) was a kind gift of Merck, Sharp \& Dohme (Rahway, NJ). The ANF used was a polypeptide consisting of 26 amino acid residues $^{2}$ of the C-terminal of the precursor 73-amino acid form of ANF (9), synthesized by a combination of classical solution and solidphase techniques as described by Seidah et al. (10). The peptide was stored in $50-\mu \mathrm{g}$ aliquots in $0.05 \mathrm{ml}$ of normal saline at $-20^{\circ} \mathrm{C}$.

\section{Results}

In the first series of experiments, we centered on the study of renal handling of $P_{i}$ and $B B M$ transport of $P_{i}$. Table $I$ summarizes the clearance data on the effects of infusion of ANF, or vehicle in controls, on FE of electrolytes, GFR, blood pressure (BP), and plasma parameters in TPTX rats from which subsequently BBMVs were isolated for BBM transport studies of $P_{i}$ in vitro. Infusion of ANF was associated, on the one hand, with significant increases in $\mathrm{FE}_{\mathrm{P}_{\mathrm{i}}}, \mathrm{FE}_{\mathrm{Na}}$, and GFR both when compared with the control period (first period) in the same animal, and also by paired analysis, i.e., compared with the matched control rats studied simultaneously. On the other hand, $\mathrm{FE}_{\mathrm{Ca}}, \mathrm{FE}_{\mathrm{Mg}}, \mathrm{FE}_{\mathrm{K}}$, or $\mathrm{BP}$ and $\mathrm{P}_{\mathrm{P}_{\mathrm{i}}}$ did not change when ANF was infused (Table I). Plasma glucose did not change with $A N F$ infusion $(137 \pm 5 \mathrm{ng} / \mathrm{dl}$, mean $\pm S E M$ in the first control period and $128 \pm 8 \mathrm{ng} / \mathrm{dl}, n=7$, during ANF infusion, second period). In the control rats infused with vehicle only, there were no changes in GFR or FE of any of the electrolytes, $\mathrm{BP}$, or $\mathbf{P}_{\mathbf{P}_{\mathbf{i}}}$ (Table I).

Table II summarizes the $\mathrm{Na}^{+}$gradient-dependent uptake
Table I. Effects of Infusion of ANF on Excretion of Electrolytes and Other Parameters in Clearance Studies in TPTX Rats Subsequently Used for Measurement of Transport of Phosphate, $\mathrm{L}$-Proline, and $\mathrm{Na}^{+}$by $\mathrm{BBMVS}$

\begin{tabular}{lcc}
\hline & First period (vehicle) & Second period" \\
\hline ANF-infused & & \\
group $(n=7)^{*}$ & & \\
$\mathrm{FE}_{\mathrm{P}_{\mathrm{i}}}(\%)$ & $3.51 \pm 1.49$ & $9.64 \pm 1.97 \ddagger \S$ \\
$\mathrm{P}_{\mathrm{P}_{\mathrm{i}}(\mathrm{mM})}$ & $2.46 \pm 0.19$ & $2.13 \pm 0.19$ \\
$\mathrm{FE}_{\mathrm{Na}}(\%)$ & $1.30 \pm 0.26$ & $4.65 \pm 0.58 \ddagger \S$ \\
$\mathrm{FE}_{\mathrm{Ca}}(\%)$ & $3.20 \pm 0.7$ & $3.70 \pm 0.5$ \\
$\mathrm{FE}_{\mathrm{K}}(\%)$ & $37.80 \pm 8.6$ & $36.20 \pm 5.5$ \\
$\mathrm{FE}_{\mathrm{Mg}}(\%)$ & $16.30 \pm 4.2$ & $20.30 \pm 5.4$ \\
$\mathrm{GFR}(\mathrm{ml} / \mathrm{min})$ & $2.17 \pm 0.31$ & $3.63 \pm 0.39 \ddagger$ \\
$\mathrm{BP}(\mathrm{mmHg})$ & $131.00 \pm 5.0$ & $131.00 \pm 5$
\end{tabular}

Control vehicleinfused group

$(n=7)^{*}$

$\mathrm{FE}(\%)$

$\mathbf{P}_{\mathrm{P}_{1}}(m M)$

$1.61 \pm 1.09$

$1.93 \pm 1.02$

$\mathrm{P}_{\mathbf{i}}(m M)$

$2.21 \pm 0.15$

$2.44 \pm 0.18$

$\mathrm{E}_{\mathrm{Na}}(\%)$

$1.01 \pm 0.29$

$2.27 \pm 1.58$

$\mathrm{FE}_{\mathrm{Ca}}(\%)$

$2.90 \pm 0.6$

$4.10 \pm 1.3$

$\mathrm{FE}_{\mathrm{K}}(\%)$

$32.20 \pm 9.2$

$26.20 \pm 3.5$

$\mathrm{FE}_{\mathrm{Mg}_{\mathrm{B}}(\%)}$

$17.50 \pm 4.6$

GFR $(\mathrm{ml} / \mathrm{min})$

$3.56 \pm 0.48$

$24.10 \pm 5.9$

BP $(m m H g)$

$130.00 \pm 3.0$

$2.63 \pm 0.58$

$128.00 \pm 3.0$

* $n$ denotes number of animals; ANF-infused animals were paired with controls.

$\ddagger \S P<0.05$ compared with control by paired $t$ test ( $\ddagger)$ or ANF with control groups by unpaired $t$ test (§).

"ANF-infused group infused with ANF in the second period; control group infused with vehicle in the second period.

of $\left[{ }^{32} \mathrm{P}\right]$ phosphate and $\mathrm{L}-\left[{ }^{3} \mathrm{H}\right]$ proline by BBMVs from ANFinfused rats and vehicle-infused control rats. Infusion of ANF decreased the concentrative $\mathrm{Na}^{+}$gradient-dependent BBMVs uptake of ${ }^{32} \mathrm{P}_{\mathrm{i}}$ both in absolute terms, i.e., net rate (picomoles per milligram of protein) and relative terms ( $\Delta \%$ overshoot) both at 15 and $30 \mathrm{~s}$. In contrast, the ${ }^{32} \mathrm{P}_{i}$ uptake at the equilibrium phase (120 min) was not different between BBMVs from controls and ANF-infused rats. In aliquots of the same BBMV preparations, the concentrative $\mathrm{Na}^{+}$gradient-dependent uptake of $\mathrm{L}-\left[{ }^{3} \mathrm{H}\right]$ proline was not different when BBMVs from ANF-infused rats were compared with controls (Table II, Fig. 1), and also, the uptake at 120 min was identical (Table II).

Likewise, the $\mathrm{Na}^{+}$gradient-dependent uptake of D$\left[{ }^{3} \mathrm{H}\right]$ glucose (expressed in picomoles per milligram of protein per $15 \mathrm{~s}$; mean \pm SEM) in BBMVs from ANF-treated rats $(588 \pm 64 ; n=4)$ was not significantly different from the $D$ $\left[{ }^{3} \mathrm{H}\right]$ glucose uptake in BBMVs from control rats $(659 \pm 35$; $n=4)$.

The diffusional uptake of ${ }^{22} \mathrm{Na}^{+}\left(\mathrm{Na}_{0}^{+}>\mathrm{Na}_{\mathrm{i}}^{+} ; \mathrm{pH}_{0}=\mathrm{pH}_{\mathrm{i}}\right)$, measured in the absence of a proton gradient (intravesicular $\mathrm{pH}$ equal to extravesicular $\mathrm{pH}$ ), was not different between BBMVs from control and from ANF-infused animals, either at $30 \mathrm{~s}$ or after equilibrium at $100 \mathrm{~min}$ (Table III). The decrease in $\mathrm{Na}^{+}$gradient-dependent uptake of ${ }^{32} \mathrm{P}_{\mathrm{i}}$ at $30 \mathrm{~s}$ by BBMVs was significantly correlated with the increase in $\mathrm{FE}_{\mathbf{P}_{\mathbf{i}}}$ determined in the same animal $(r=0.99 ; P<0.001 ; t$ test, $n$ $=7$ ), but not with $\mathrm{FE}_{\mathrm{K}}, \mathrm{FE}_{\mathrm{Ca}}$, or $\mathrm{FE}_{\mathrm{Mg}_{\mathrm{g}}}$. In contrast, the $\mathrm{FE}_{\mathrm{P}_{\mathbf{i}}}$ 
Table II. Effects of ANF Infusion on BBMV Transport of ${ }^{32} P_{i}$ and $L-\left[{ }^{3} H\right]$ Proline (See Table I)

\begin{tabular}{lll}
\hline Time & $\begin{array}{l}\text { Controls } \\
(n=7)\end{array}$ & $\begin{array}{l}\text { ANF-treated } \\
(n=7)\end{array}$ \\
\hline & pmol/mg protein & pmol/mg protein \\
{$\left[{ }^{32} \mathrm{P}_{\mathrm{i}}\right]$ Phosphate } & & \\
uptake & $1,862 \pm 69^{*}$ & $1,378 \pm 35 \ddagger$ \\
$15 \mathrm{~s}$ & $2,286 \pm 152$ & $1,755 \pm 143 \ddagger$ \\
$30 \mathrm{~s}$ & $803 \pm 56$ & $752 \pm 66$ \\
$120 \mathrm{~min}$ & $150 \pm 22$ & $102 \pm 21 \ddagger$ \\
$\% \Delta_{15 s} \S$ & $194 \pm 29$ & $141 \pm 22 \ddagger$ \\
$\% \Delta_{30 \mathrm{~s}} \S$ & & \\
$\mathrm{L}-\left[{ }^{3} \mathrm{H}\right] \mathrm{Proline}$ & & \\
uptake & & $280 \pm 29$ \\
$15 \mathrm{~s}$ & $286 \pm 33^{*}$ & $38 \pm 4$ \\
120 min & $41 \pm 4$ & $644 \pm 86$ \\
$\% \Delta_{15 s} \S$ & $607 \pm 103$ & \\
\hline
\end{tabular}

* Mean \pm SEM of seven experiments; controls and ANF-treated were paired.

‡ Significantly different from corresponding control values $(P<0.05)$ by paired $(*)$ or group ( $\ddagger) t$ test.

§ Ratio of initial uptake ("overshoot") expressed relative to equilibrium point $(120 \mathrm{~min})$.

did not correlate with the rate of ${ }^{22} \mathrm{Na}^{+}$uptake by BBMVs at $30 \mathrm{~s}$, or with uptake of $\mathrm{L}-\left[{ }^{3} \mathrm{H}\right]$ proline.

The effect of direct addition of ANF in vitro on $P_{i}$ transport was measured in BBMVs prepared from nontreated rats. BBMVs were preincubated with ANF $\left(4 \mathrm{ng} / \mathrm{ml}\right.$ in a $\mathrm{Na}^{+}$-free buffer) in vitro for $30 \mathrm{~s}$ at $20^{\circ} \mathrm{C}$ and then the $\mathrm{Na}$ gradient-
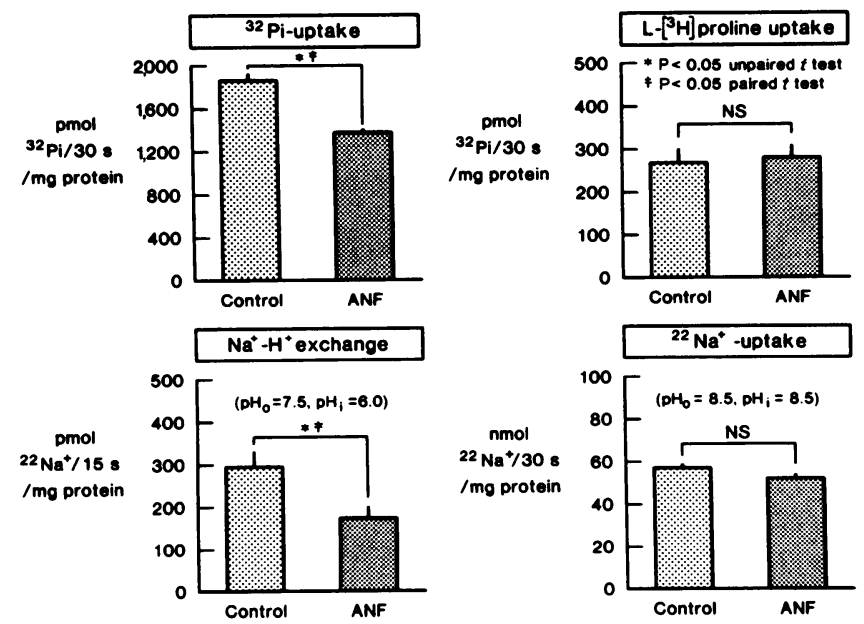

Figure 1. Transport properties of renal cortical BBMVs from rats infused with vehicle (control) and rats infused with ANF peptide (ANF). The $\mathrm{Na}^{+}$-dependent uptake of $\mathrm{P}_{\mathrm{i}}$ and $\mathrm{L}-\left[{ }^{3} \mathrm{H}\right]$ proline, as well as the uptake of ${ }^{22} \mathrm{Na}^{+}$and amiloride-sensitive $\mathrm{Na}^{+}-\mathrm{H}^{+}$exchange were measured in the initial $(15 \mathrm{~s}, 30 \mathrm{~s})$ time periods. Each bar denotes mean $\pm \mathrm{SE}$ of paired experiments $\left({ }^{32} \mathrm{P}_{\mathrm{i}}\right.$ and $\mathrm{L}-\left[{ }^{3} \mathrm{H}\right]$ proline, $n=7 ;{ }^{22} \mathrm{Na}^{+}$ uptake, $n=6$; amiloride-sensitive $\mathrm{Na}^{+}-\mathrm{H}^{+}$exchange, $n=4$ ). Asterisk $(*)$ denotes statistically significant difference from controls based on group comparison $(P<0.05$, unpaired $t$ test). Double dagger $(\ddagger)$ denotes statistically significant difference from controls based on paired comparison (paired $t$ test, $P<0.05$ ).
Table III. Uptake of ${ }^{22} \mathrm{Na}^{+}$in the Absence of $\mathrm{pH}$ Gradient $\left(p \mathrm{H}_{0}=p \mathrm{H}_{i} ; \mathrm{Na} a_{0}^{+}=100 \mathrm{mM} ; \mathrm{Na}_{i}^{+}=0\right)$

by $B B M V$ from Control and from ANF-treated Rats

\begin{tabular}{lll}
\hline & \multicolumn{2}{l}{${ }^{22} \mathrm{Na}^{+}$uptake } \\
\cline { 2 - 3 } Animals & $30 \mathrm{~s}$ & $120 \mathrm{~min}$ \\
\hline & $n m o l / m g$ protein & $n m o l / m g$ protein \\
Controls & $57 \pm 2^{*}$ & $185 \pm 11$ \\
ANF-treated & $52 \pm 2$ & $166 \pm 10$ \\
\hline
\end{tabular}

* All values are mean \pm SEM of six experiments. Uptake of ${ }^{22} \mathrm{Na}^{+}$in BBMVs from ANF-infused rats was not significantly different from controls ( $t$ test).

dependent uptake of ${ }^{32} \mathrm{P}_{\mathrm{i}}$ was measured after $30 \mathrm{~s}$, as described in Methods. Under these experimental conditions, the rate of $P_{i}$ uptake was not changed by the presence of ANF (data not shown).

In the next series of experiments, we studied the effect of ANF on $\mathrm{HCO}_{3}$ excretion and $\mathrm{Na}^{+}-\mathrm{H}^{+}$antiport in BBMVs. Table IV summarizes the clearance data and Table $\mathrm{V}$, the analysis of the rate of $\mathrm{Na}^{+}-\mathrm{H}^{+}$exchange across BBMVs

Table IV. Effects of Infusion of ANF on Excretion of Electrolytes and Other Parameters in TPTX Rats Subsequently Used for Measurements of $\mathrm{Na}^{+}-\mathrm{H}^{+}$Exchange in BBMV Studies (See Table V)

\begin{tabular}{lcc}
\hline & First period (vehicle) & Second period" \\
\hline ANF-infused & & \\
group $(n=8)^{*}$ & & \\
$\mathrm{FE}_{\mathrm{HCO}_{3}(\%)}$ & $5.87 \pm 2.14$ & $9.99 \pm 1.99 \ddagger \S$ \\
$\mathrm{FE}_{\mathrm{Na}^{\prime}}(\%)$ & $1.06 \pm 0.26$ & $3.73 \pm 0.72 \ddagger \S$ \\
$\mathrm{FE}_{\mathrm{P}_{\mathrm{i}}(\%)}(\%)$ & $4.99 \pm 1.97 \ddagger \S$ \\
$\mathrm{FE}_{\mathrm{Ca}}(\%)$ & $0.84 \pm 0.41$ & $2.80 \pm 0.6$ \\
$\mathrm{FE}_{\mathrm{K}}(\%)$ & $2.00 \pm 0.6$ & $30.00 \pm 5.0$ \\
$\mathrm{GFR}(\mathrm{ml} / \mathrm{min})$ & $26.80 \pm 2.9$ & $4.41 \pm 0.53 \ddagger \S$ \\
$\mathrm{BP}(\mathrm{mmHg})$ & $2.92 \pm 0.27$ & $130.00 \pm 5.0$ \\
$\mathrm{P}_{\mathrm{PO}_{4}(m M)}(\mathrm{mM})$ & $29.00 \pm 5.0$ & $2.97 \pm 0.20$ \\
$\mathrm{P}_{\mathrm{HCO}_{3}}(\mathrm{mM})$ & $27.06 \pm 0.07$ & $27.00 \pm 1.00$
\end{tabular}

Control vehicleinfused group $(n=8)^{*}$

$\mathrm{FE}_{\mathrm{HCO}}(\%)$

$\mathrm{FE}_{\mathrm{Na}}(\%)$

$\mathrm{FE}_{\mathrm{P}_{\mathrm{i}}}(\%)$

$\mathrm{FE}_{\mathrm{K}}(\%)$

GFR $(\mathrm{ml} / \mathrm{min})$

BP $(m m H g)$

$\mathrm{P}_{\mathrm{PO}_{4}}(m M)$

$\mathbf{P}_{\mathrm{HCO}_{3}}(m M)$

$5.62 \pm 1.38$
$1.17 \pm 0.24$
$0.69 \pm 0.25$
$28.30 \pm 6.2$
$2.88 \pm 0.38$
$130.00 \pm 4.0$
$3.04 \pm 0.17$
$27.00 \pm 1.00$

$6.09 \pm 1.60$

$0.92 \pm 0.26$

$0.90 \pm 0.38$

$23.40 \pm 5.4$

$2.72 \pm 0.47$

$129.00 \pm 5.0$

$2.97 \pm 0.15$

$27.00 \pm 1.00$

${ }^{*} n$ denotes number of animals; controls and ANF-infused animals were paired.

$\ddagger \S P<0.05$ compared with control by paired $t$ test ( $\ddagger)$ or ANF with control groups by unpaired $t$ test (§).

" ANF-infused group infused with ANF in the second period; control group infused with vehicle in the second period. 
Table $V$. Effect of ANF Infusion on the Rate of $\mathrm{Na}^{+}-\mathrm{H}^{+}$Exchange across $\mathrm{BBMVS}$ in the Presence of Proton Gradient $\left[\mathrm{H}_{i}^{+}>\mathrm{H}_{0}^{+}\right]$

\begin{tabular}{lll}
\hline & \multicolumn{2}{l}{${ }^{22} \mathrm{Na}^{+}$uptake } \\
\cline { 2 - 3 } & $15 \mathrm{~s}$ & $120 \mathrm{~min}$ \\
\hline Controls & & \\
- Amiloride & $539 \pm 33^{*}$ & $1,275 \pm 66$ \\
+ Amiloride & $244 \pm 11$ & $1,430 \pm 81$ \\
Amiloride-sensitive & $295 \pm 36$ & - \\
ANF-treated & & \\
- Amiloride & $448 \pm 26 \ddagger \S$ & $1,222 \pm 63$ \\
+ Amiloride & $275 \pm 5 \ddagger \S$ & $1,346 \pm 98$ \\
Amiloride-sensitive & $173 \pm 28 \ddagger \S$ & - \\
\hline
\end{tabular}

${ }^{22} \mathrm{Na}^{+}$uptake was measured with or without added amiloride. The "amiloride-sensitive" uptake was determined as a differential of uptake in the presence and in the absence of $1 \mathrm{mM}$ amiloride, measured in the same BBMV preparation.

* All values are mean \pm SEM of four experiments (pooled tissue from eight rats).

$\ddagger \S$ Significantly different from corresponding control values $(P<0.05$ or higher degree of significance; paired $t$ test $(\ddagger)$, group $t$ test( $(\S)$.

prepared from the same animals. As in the first series of experiments (Table I), the infusion of ANF was associated with significant increases in $F E_{\mathrm{Na}}, \mathrm{FE}_{\mathrm{P}_{\mathrm{i}}}$, and GFR. The $\mathrm{FE}_{\mathrm{HCO}_{3}}$ was markedly increased after ANF infusion (second period) both when compared with the first control period in the same animals, or when compared with the control group receiving vehicle only in the second period (Table IV). Again, as in previous experiments, the $\mathrm{FE}$ of $\mathrm{Ca}^{2+}$ and $\mathrm{K}^{+}, \mathrm{BP}$, and $P_{\mathrm{P}_{i}}$ and $\mathrm{P}_{\mathrm{HCO}_{3}}$ did not change when ANF was infused (Table IV). Likewise, the pH and $\mathrm{PCO}_{2}$ did not change in response to ANF (data not shown). In the control group (Table IV), there was no change in GFR, FE of any electrolytes, BP, or $P_{P_{i}}$

Table $\mathrm{V}$ summarizes the effects of ANF infusion on the rate of $\mathrm{Na}^{+}-\mathrm{H}^{+}$exchange across BBMVs in the presence of a proton gradient. The total ${ }^{22} \mathrm{Na}^{+}$uptake rate $(15 \mathrm{~s})$ in the presence of $\mathrm{H}^{+}$gradient $\left(\mathrm{H}_{\mathrm{i}}^{+}>\mathrm{H}_{0}^{+}\right)$was significantly lower $(-17 \%)$ in BBMVs for ANF-infused rats. The difference between BBMVs from control and ANF-infused rats was even more pronounced $(-41 \%)$ in the amiloride-sensitive component of $\mathrm{Na}^{+}-\mathrm{H}^{+}$exchange across BBM (Table V). After equilibration $(120 \mathrm{~min})$ the ${ }^{22} \mathrm{Na}^{+}$uptake did not differ between control and ANF-infused rats (Table V).

The rate of $\mathrm{H}^{+}$efflux from BBMVs $\left[\mathrm{H}_{\mathrm{i}}^{+}>\mathrm{H}_{0}^{+}\right]$in the absence of $\mathrm{Na}^{+}$was determined using the quenching and subsequent reappearance of $\mathrm{AO}$ fluorescence as an indicator of the transmembrane proton-gradient dissipation, is shown in Table VI. The rates of relative increase in the AO fluorescence intensity at 15- and 30-s intervals measured under similar conditions for control and ANF-treated vesicles were not different. These results indicate that the $\mathrm{H}^{+}$conductance of the BBM was not increased, and hence, cannot account for decreased $\mathrm{Na}^{+}-\mathrm{H}^{+}$exchange rate in BBMVs from ANF-treated rats.

To explore the relationship between changes in excretions of $\mathrm{Na}^{+}$and other electrolytes elicited by ANF, we examined
Table VI. Effect of ANF Administration In Vivo on the Rate of Dissipation of Proton Gradient $\left[\mathrm{H}_{i}^{+}>\mathrm{H}_{0}^{+}\right]$across BBMV

\begin{tabular}{llll}
\hline & & \multicolumn{2}{l}{$+\Delta \%$ Fluorescence } \\
\cline { 3 - 4 } Experiment & Condition & $15 \mathrm{~s}$ & $30 \mathrm{~s}$ \\
\hline 1 & Controls & $17.3 \pm 0.5^{*}$ & $30.0 \pm 1.1$ \\
& ANF-treated & $17.4 \pm 0.4$ & $31.2 \pm 1.1$ \\
2 & Controls & $20.0 \pm 1.1$ & $34.6 \pm 1.1$ \\
& ANF-treated & $20.2 \pm 0.5$ & $36.4 \pm 1.2$ \\
\hline
\end{tabular}

The proton efflux was determined as a rate of return of $\mathrm{AO}$ fluorescence in relative (\%) units. For further details, see Methods.

* Each number denotes mean \pm SEM of five measurements.

correlations between changes $(\Delta)$ in $\mathrm{FE}_{\mathrm{Na}}$ and $\mathrm{FE}$ of other simultaneously measured ions. Table VII summarizes the correlation of change in $\mathrm{FE}$ of $\mathrm{Na}^{+}\left(\Delta \mathrm{FE}_{\mathrm{Na}^{+}}\right)$with the change in $\mathrm{FE}$ of phosphate $\left(\Delta \mathrm{FE}_{\mathrm{P}_{\mathrm{i}}}\right)$, bicarbonate $\left(\Delta \mathrm{FE}_{\mathrm{HCO}_{3}}\right)$, potassium $\left(\Delta \mathrm{FE}_{\mathrm{K}}\right)$, magnesium $\left(\Delta \mathrm{FE}_{\mathrm{Mg}}\right)$, and calcium $\left(\Delta \mathrm{FE}_{\mathrm{Ca}}\right)$. Results show that $\Delta \mathrm{FE}_{\mathrm{Na}}$ correlated significantly with $\Delta \mathrm{FE}_{\mathrm{P}_{\mathbf{i}}}$ and $\Delta \mathrm{FE}_{\mathrm{HCO}_{3}}$, but not with $\Delta \mathrm{FE}_{\mathrm{K}}, \Delta \mathrm{FE}_{\mathrm{Mg}}$, or $\Delta \mathrm{FE}_{\mathrm{Ca}}$.

\section{Discussion}

As expected from previous reports $(1,4)$, infusion of ANF peptide significantly increased the $\mathrm{FE}_{\mathrm{Na}^{+}}$in TPTX rats. Even more importantly, ANF infusion also significantly decreased reabsorption of $\mathrm{P}_{\mathrm{i}}$ and $\mathrm{HCO}_{3}$ anions, the bulk of which are reabsorbed from glomerular filtrate in proximal tubules. As in other studies (1-5), infusion of ANF increases GFR, and hence, filtered loads of solutes, including $\mathrm{Na}^{+}, \mathrm{HCO}_{3}$, and $\mathrm{P}_{\mathrm{i}}$. When electrolyte excretions are expressed as $\mathrm{FE}$ relative to filtered amount, it should be realized that net tubular reabsorption of solutes is increased. However, in response to ANF, the amount of reabsorbed $\mathrm{Na}^{+}, \mathrm{HCO}_{3}$, and $\mathrm{P}_{\mathrm{i}}$ is less than proportional to filtered loads due to increased GFR and such phenomenon indicates that tubular reabsorptive transport is inhibited by ANF. The decreased reabsorptions of $P_{i}$ and $\mathrm{HCO}_{3}$ were specific because the $\mathrm{FE}$ of $\mathrm{Ca}^{2+}, \mathrm{K}^{+}$, and $\mathrm{Mg}^{2+}$ were not affected. In that our experiments were conducted in TPTX rats, the effects of ANF peptide cannot be explained by an effect on the release or potentiation of action of endogenous

Table VII. Correlation between Changes in Fractional Excretion of Sodium $\left(\Delta F E_{N a}\right)$ and Changes in Fractional Excretions ( $\triangle F E$ ) of Other Measured Electrolytes

\begin{tabular}{llll}
\hline Change & $r^{*}$ & $n \ddagger$ & $P$ value§ \\
\hline$\Delta \mathrm{FE}_{\mathrm{Pi}_{\mathrm{i}}}$ & 0.90 & 7 & $<0.01$ \\
$\Delta \mathrm{FE}_{\mathrm{HCO}_{3}}$ & 0.89 & 7 & $<0.01$ \\
$\Delta \mathrm{FE}_{\mathrm{K}}$ & 0.71 & 7 & NS \\
$\Delta \mathrm{FE}_{\mathrm{Ca}}$ & 0.62 & 7 & NS \\
$\Delta \mathrm{FE}_{\mathrm{Mg}}$ & 0.60 & 7 & NS
\end{tabular}

* Correlation coefficient.

$\ddagger$ Number of pairs.

$\S$ For significance of $r, t$ test. 
parathyroid hormone (PTH) or calcitonin, polypeptide hormones that are well known to increase renal excretion of $P_{i}$ and $\mathrm{HCO}_{3}(34)$, or by removal of the antiphosphaturic effects of thyroid hormones (22).

ANF-elicited changes in the $\mathrm{FE}_{\mathrm{Na}}$ showed a strong positive correlation with changes in $\mathrm{FE}_{\mathrm{P}_{\mathbf{1}}}$ and $\mathrm{FE}_{\mathrm{HCO}_{3}}$, whereas no significant correlation was noted with $\mathrm{FE}_{\mathrm{Ca}}, \mathrm{FE}_{\mathrm{M}_{\mathrm{g}}}$, or $\mathrm{FE}_{\mathrm{K}}$ (Table VII). These correlative relationships further suggest that ANF peptide inhibited reabsorption of $\mathrm{Na}^{+}$, which is linked to proximal tubular reabsorption of $\mathrm{P}_{\mathrm{i}}$ and $\mathrm{HCO}_{3}$. This suggestion is strongly supported by findings of changed transport properties of BBMVs isolated from the same rats. Of particular interest is a finding that $\mathrm{Na}^{+}$gradient-dependent uptake of $\mathrm{Pi}$ was markedly inhibited in response to infusion of ANF peptide (Table II, Fig. 1). A lack of any effect of the infusion of ANF peptide on the (30 s) diffusional ${ }^{22} \mathrm{Na}^{+}$uptake by BBMV (Table III), or on other transport systems energized by $\left(\mathrm{Na}_{0}^{+}>\mathrm{Na}_{\mathrm{i}}^{+}\right)$ gradient, i.e., the uptake of $\mathrm{L}-\left[{ }^{3} \mathrm{H}\right]$ proline and $\mathrm{D}-\left[{ }^{3} \mathrm{H}\right] \mathrm{glu}$ cose indicate that the inhibition elicited by infusion of ANF peptide is relatively specific for the BBM transport system for $P_{i}$ (Table III, Fig. 1). Therefore, the decrease in the $\mathrm{Na}^{+}$ dependent $P_{i}$ uptake is not due to increased diffusional permeability of BBM for $\mathrm{Na}^{+}$, hence the faster dissipation of $\left(\mathrm{Na}_{0}^{+}>\mathrm{Na}_{\mathrm{i}}^{+}\right)$gradient in response to the infused ANF peptide (35). Furthermore, the observations that BBMV uptake of $\mathrm{L}$ $\left[{ }^{3} \mathrm{H}\right]$ proline and of ${ }^{22} \mathrm{Na}^{+}$after complete equilibration (120 min) (Tables II and III) is not different after the infusion of ANF peptide indicate that intravesicular BBMV volume is not altered $(14,21)$. Therefore, the observed decrease in $\mathrm{Na}^{+}$ gradient-dependent BBMV uptake of $P_{i}$ provides a strong argument for the notion that proximal tubular $P_{i}$ reabsorption was reduced in response to ANF. As in the case of other hormones that modulate $B B M$ transport of $P_{i}$ in vivo but not in vitro, e.g., PTH (35a), glucocorticoids (28), or $\mathrm{T}_{4}$ (22) direct interaction of ANF with the BBM in vitro had no effect. This indicates that $A N F$ requires other cellular components and/or intact cells for expression of its effect on the BBM transport system.

The $\mathrm{Na}^{+}-\mathrm{H}^{+}$antiport at the BBM, a major component of $\mathrm{HCO}_{3}$-linked proximal tubular $\mathrm{Na}^{+}$reabsorption $(11,15-17$, 36), was markedly blunted by ANF-peptide infusion (Table V). This decreased capacity of the $\mathrm{Na}^{+}-\mathrm{H}^{+}$exchange mechanism in the BBM may be the basis of diminished $\mathrm{Na}^{+}$-linked $\mathrm{HCO}_{3}$ reabsorption in proximal tubules, which in turn increases $\mathrm{FE}_{\mathrm{HCO}_{3}}$ (Table IV) $(15,16,36,37)$. A finding that ANF infusion does not lead to change in $\mathrm{H}^{+}$conductance of the BBM, and hence, in the rate of dissipation of $\left[\mathrm{H}_{\mathrm{i}}^{+}>\mathrm{H}_{0}^{+}\right]$gradient, suggests that alteration of $\mathrm{Na}^{+} / \mathrm{H}^{+}$antiporter within the $\mathrm{BBM}$ is a basis of lower rate of $\mathrm{Na}^{+}$luminal entry in exchange to $\mathrm{H}^{+}(25,26)$. Besides luminal entry across BBM, another major component operative in transepithelial $\mathrm{Na}^{+}$reabsorption and in $\mathrm{Na}^{+}$linked transport systems in proximal tubules is the activity of $\left(\mathrm{Na}^{+}-\mathrm{K}^{+}\right)$-ATPase at basolateral membranes, an active $\mathrm{Na}^{+}$ pump that continuously maintains low intracellular $\mathrm{Na}^{+}$and lumen-to-cell $\mathrm{Na}^{+}$gradient (11-15). Studies reported by other investigators show that ANF does not influence $\left(\mathrm{Na}^{+}-\mathrm{K}^{+}\right)$ATPase activity (4-6).

Taken together, the observations that the rate of $\mathrm{Na}^{+}-\mathrm{H}^{+}$ antiport and $\mathrm{Na}^{+}-\mathrm{Pi}$ synport of BBM was diminished (Fig. 1) indicate that ANF-peptide inhibited at least in part the $\mathrm{Na}^{+}$ reabsorption and reabsorption of solutes cotransported with $\mathrm{Na}^{+}$in proximal tubules $(19,20,38-40)$. It remains to be further explored whether or not the changes in BBM transport consequent to ANF infusion are the only and/or the primary basis of altered urinary electrolyte excretion.

Major qualifications and potential limitations in the interpretation of the present observations should be briefly mentioned. First, the ANF peptide was infused in vivo, and it is not possible at the present time to conclude whether the changes in renal function $(\triangle \mathrm{FE})$ and the $B B M$ effects were due to the direct action of this peptide on the proximal tubular cells or whether ANF acts through some indirect mechanism. In that ANF does not inhibit transport by direct addition in vitro, it is unlikely to interact with BBM transporters directly and requires the whole cell for its action. Conceivably, the ANF peptide can also be biotransformed in vivo to the substance, e.g., the proteolytic peptide fragment, that may be the compound directly interacting with proximal tubules. Also, ANF administration may affect release of endogenous factors that could influence the renal response, such as aldosterone (41). PTH, calcitonin, and glucagon can be excluded based on the experimental design-TPTX rats and findings of the lack of changes in the glucose level. Moreover, the possibility that ANF would act on tubular receptors for PTH or calcitonin or glucagon is unlikely, because the ANF-peptide does not share an homologous amino acid sequence with any other known biologically active peptide (42). The time course and reversibility of the infused ANF peptide on BBM transport systems remain to be explored. Second, the substantial increases in GFR (Tables I and IV) may contribute to the increases in FE of electrolytes. It is highly unlikely that the entire effect is due to hemodynamic changes, as indicated by recent study on anesthetized dogs (43).

It is a most plausible explanation that the diminished luminal entry of $\mathrm{P}_{\mathrm{i}}$ with $\mathrm{Na}^{+}$and in exchanges with $\mathrm{H}^{+}$ account for the lower rate of proximal tubule reabsorption of these solutes.

In summary, the present observations indicate that ANF peptide (and possibly other derivatives of this peptide hormone family) cause phosphaturia and bicarbonaturia, and inhibit the $\mathrm{Na}^{+}$-linked transport process in the proximal segments of the tubules. Therefore, the effect of ANF on proximal tubular transport of solutes constitutes another component of renal actions $(1,4)$ of this intriguing, newly found regulatory substançe.

\section{Acknowledgments}

Mrs. Marcine Onsgard, Ms. Susan Mulroney, and Ms. Susan Gapstur provided expert technical assistance. Ms. Jacque Trefz and Mrs. Carolyn Blankenship provided excellent secretarial assistance. We are grateful to Dr. E. H. Blaine of the Merck, Sharp \& Dohme Laboratory, West Point, PA, for a generous supply of synthetic ANF.

This research was supported by grants AM-30759 and AM-19715 from the National Institutes of Health and by the Mayo Foundation. Dr. Hammond was supported by training grant AM-07013 from the National Institutes of Health, and a travel grant from CIBA-Geigy (Australia) Ltd.

\section{References}

1. Sagnella, G. A., and G. A. MacGregor. 1984. Cardiac peptides and the control of sodium excretion. Nature (Lond.). 390:666-667.

2. Oshima, T., M. G. Currie, D. M. Geller, and P. Needleman. 1984. An atrial peptide is a potent renal vasodilator substance. Circ. Res. 54:612-616.

3. Camargo, M. J. F., H. D. Kleinert, S. A. Atlas, J. E. Sealey, J. H. Laragh, and T. Maack. 1984. Ca-dependent hemodynamic and 
natriuretic effects of atrial extract in isolated rat kidney. Am. J. Physiol. 246:F447-F456

4. Grantham, J. J., and R. M. Edwards. 1984. Natriuretic hormones: At last, bottled in bond? J. Lab. Clin. Med. 103:333-336.

5. Pamnani, M. B., D. L. Clough, J. S. Chen, W. T. Link, and F. J. Haddy. 1984. Effects of rat atrial extract on sodium transport and blood pressure in the rat (41851). Proc. Soc. Exp. Biol. Med. 176: 123-131.

6. Pollock, D. M., M. M. Mullins, and R. O. Banks. 1983. Failure of atrial myocardial extract to inhibit renal $\mathrm{Na}^{+}, \mathrm{K}^{+}$-ATPase. Renal Physiol. 6:295-299.

7. Sonnenberg, H., A. Cupples, A. J. deBold, and A. T. Veress. 1982. Intrarenal localization of the natriuretic effect of cardiac atrial extract. Can. J. Physiol. Pharmacol. 60:1149-1152.

8. Briggs, J. P., B. Steipe, G. Schubert, and J. Schnermann. 1982. Micropuncture studies of the renal effects of atrial natriuretic substance. Pflügers Arch. Eur. J. Physiol. 395:271-276.

9. Thibault, G., R. Garcia, N. G. Seidah, C. Lazure, M. Cantin, M. Chretien and J. Genest. 1983. Purification of three rat atrial natriuretic factors and their amino acid composition. FEBS (Fed. Eur. Biochem. Soc.) Lett. 164:286-290.

10. Seidah, N. H., C. Lazure, M. Chretien, G. Thibault, R. Garcia, M. Cantin, J. Genest, R. F. Nutt, S. F. Brady, T. A. Lyle, W. J. Paleveda, C. D. Colton, T. M. Ciccarone, and D. F. Veber. 1984. Amino acid sequence of homologous rat atrial peptides: natriuretic activity of native and synthetic forms. Proc. Natl. Acad. Sci. USA. 81: 2640-2644.

11. Ullrich, K. J., G. Rumrich, and S. Kloss. 1982. Transport of inorganic and organic substances in the renal proximal tubule. Klin. Wochenschr. 60:1165-1172.

12. Ullrich, K. J. 1980. Mode of inhibition of the proximal renal transport processes. In Renal Pathophysiology. A. Leaf and G. Giebisch, editors. Raven Press, New York. 121-128.

13. Dousa, T. P., and S. A. Kempson. 1982. Regulation of renal brush border transport of phosphate. Miner. Electrolyte Metab. 7:113121.

14. Murer, H., and R. Kinne. 1980. The use of isolated membrane vesicles to study epithelial transport processes. J. Membr. Biol. 55:8195.

15. Rector, F. C., Jr. 1983. Sodium, bicarbonate, and chloride absorption by the proximal tubule. Am. J. Physiol. 244:F461-F471.

16. Chantrelle, B., M. G. Cogan, and F. C. Rector, Jr. 1982. Evidence for coupled sodium/hydrogen exchange in the rat superficial proximal convoluted tubule. Pflügers Arch. Eur. J. Physiol. 395:186189.

17. Kinsella, J. L., and P. S. Aronson. 1981. Amiloride inhibition of the $\mathrm{Na}^{+}-\mathrm{H}^{+}$exchanger in renal microvillus membrane vesicles. $\mathrm{Am}$. J. Physiol. 241:F374-F379.

18. Reenstra, W. W., D. S. Warnock, V. J. Yee, and J. G. Forte. 1981. Proton gradient in renal cortex brush border membrane vesicles: Demonstration of a rheogenic proton flux with acridine orange. J. Biol. Chem. 256:11663-11666.

19. Frieberg, J. M., J. Kinsella, and B. Sacktor. 1982. Glucocorticoids increase the $\mathrm{Na}^{+}-\mathrm{H}^{+}$exchange and decrease the $\mathrm{Na}^{+}$gradient-dependent phosphate-uptake systems in renal brush border membrane vesicles. Proc. Natl. Acad. Sci. USA. 79:4932-4936.

20. Cohn, D. E., S. Klahr, and M. R. Hammerman. 1983. Metabolic acidosis and parathyroidectomy increase $\mathrm{Na}^{+}-\mathrm{H}^{+}$exchange in brush border vesicles. Am. J. Physiol. 245:F217-F222.

21. Kempson, S. A., S. V. Shah, P. G. Werness, T. Berndt, P. H. Lee, L. H. Smith, F. G. Knox, and T. P. Dousa. 1980. Renal brush border membrane adaptation to phosphorus deprivation: effects of fasting compared to low phosphorus diet. Kidney Int. 18:36-47.

22. Espinosa, R. E., M. J. Keller, A. N. K. Yusufi, and T. P. Dousa. 1984. Effect of thyroxine administration on phosphate transport across renal cortical brush border membrane. Am. J. Physiol. 246: F133-F139.

23. Kempson, S. A., G. Colon-Otero, S. Y. L. Ou, S. T. Turner, and T. P. Dousa. 1981. Possible role of nicotinamide-adenine dinucle- otide as an intracellular regulator of renal transport of phosphate in the rat. J. Clin. Invest. 67:1347-1360.

24. Booth, A. G., and A. J. Kenny. 1974. A rapid method for the preparation of microvilli from rabbit kidney. Biochem. $J$. 142:575581.

25. Tsai, C-J., H. E. Ives, R. J. Alpern, V. J. Lee, D. G. Warnock, and F. C. Rector, Jr. 1984. Increased $V \max$ for $\mathrm{Na}^{+} / \mathrm{H}^{+} /$antiporter activity in proximal tubule brush border vesicles from rabbits with metabolic acidosis. Am. J. Physiol. 247:F339-F343.

26. Sabolic, I., and G. Burckhardt. 1984. Effect of the preparation method on $\mathrm{Na}^{+}-\mathrm{H}^{+}$exchange and ion permeabilities in rat renal brush-border membranes. Biochim. Biophys. Acta. 772:140-148.

27. Cohn, D. E., K. A. Hruska, S. Klahr, and M. R. Hammetman. 1982. Increased $\mathrm{Na}^{+}-\mathrm{H}^{+}$exchange in brush border vesicles from dogs with renal failure. Am. J. Physiol. 243:F293-F299.

28. Turner, S. T., G. M. Kiebzak, and T. P. Dousa. 1982. Mechanism of glucocorticoid effect on renal transport of phosphate. Am. J. Physiol. 143:C227-C236.

29. Kempson, S. A., T. J. Berndt, S. T. Turner, D. Zimmerman, F. Knox, and T. P. Dousa. 1983. Relationship between renal phosphate reabsorption and renal brush border membrane transport. Am. J. Physiol. 244:R216-R223.

30. Lowry, O. H., N. J. Rosebrough, A. L. Farr, and R. J. Randall. 1951. Protein measurement with the Folin phenol reagent. J. Biol. Chem. 193:265-275.

31. Chen, P., R. Toribara, and H. E. Warner. 1956. Microdetermination of phosphorus. Anal. Chem. 28:1756-1758.

32. Fuhr, J., J. Kaczmerkzyk, and C. D. Kruttgen. 1955. Eine einfache colorimetrische Methode zur Inulinbestimmung für NierenClearance-Untersuchungen bei Stoffwechselgesunden und Diabetikern. Klin. Wochenschr. 33:729-730.

33. Natelson, S. 1951. Routine use of ultramicromethods in the clinical laboratory. Am. J. Clin. Pathol. 21:1153-1173.

34. Agus, Z. S., A. Wasserstein, and S. Goldfarb. 1981. PTH, calcitonin, cyclic nucleotides and the kidney. Annu. Rev. Physiol. 43: 583-595.

35. Hruska, K. A., S. Klahr, and M. R. Hammerman. 1982. Decreased luminal membrane transport of phosphate in chronic renal failure. Am. J. Physiol. 242:F17-F22.

35a. Evers, C., H. Murer, and R. Kinne. 1978. Effect of parathyrin on the transport properties of isolated renal brush-border vesicles. Biochem. J. 172:49-56.

36. Kinsella, J. L., and P. S. Aronson. 1980. Properties of the $\mathrm{Na}^{+}-$ $\mathrm{H}^{+}$exchanger in renal microvillus membrane vesicles. Am. J. Physiol. 238:F461-F469.

37. Pollock, A. S., D. G. Warnock, and G. J. Strewler. 1984. Parathyroid hormone induced decrease in $\mathrm{Na}^{+} / \mathrm{H}^{+}$antiporter activity in a cultured opossum kidney cell line. IXth International Congress of Nephrology. 387a. (Abstr.)

38. Kinsella, J. L., and B. Sacktor. 1984. Thyroid hormones affect $\mathrm{Na}^{+}-\mathrm{H}^{+}$exchange and $\mathrm{Na}^{+}$-phosphate $(\mathrm{Pi})$ co-transport in renal brush border membrane vesicles (BB). Fed. Proc. 43:633. (Abstr.)

39. Ulrich, F. M., J. Kelley, and C. A. Vaamonde. 1979. Impaired renal bicarbonate reabsorption in the hypothyroid rat. Am. J. Physiol. 236:F536-F540.

40. Yusufi, A. N. K., N. Murayama, J. M. Keller, and T. P. Dousa. 1985. Modulatory effect of thyroid hormones on uptake of phosphate and other solutes across luminal brush border membrane of kidney cortex. Endocrinology. 116:2438-2449.

41. Atarashi, K., P. J. Mulrow, R. Franco-Saeny, R. Snajder, and $J$. Rapp. 1984. Inhibition of aldosterone production by an atrial extract. Science (Wash. DC). 224:992-993.

42. Flynn, T. G., M. L. deBold, and W. J. deBold. 1983. The amino acid sequence of an atrial peptide with potent diuretic and natriuretic properties. Biochem. Biophys. Res. Commun. 117:859-865.

43. Burnett, J. C., Jr., J. P. Granger, and T. J. Opgenorth. 1984. Effects of synthetic atrial natriuretic factor on renal function and renin release. Am. J. Physiol. 76:F863-F866. 